\title{
Grasses Control Strategies in Setting Restoration Stand of the Atlantic Forest
}

João Elves da Silva Santana ${ }^{1}$ (1) 0000-0003-1363-0370

Paulo Sérgio dos Santos Leles ${ }^{1}$ (D) 0000-0002-8393-6095

Alexander Silva de Resende ${ }^{2}$ (1) 0000-0002-1433-9203

Aroldo Ferreira Lopes Machado ${ }^{1}$ (D) 0000-0001-6506-9728

Juçara Garcia Ribeiro ${ }^{1}$ (D) 0000-0003-0426-6212

Rodrigo Ferreira Gomes ${ }^{1}$ (D) 0000-0001-7635-2772

\begin{abstract}
This study aimed to assess the effectiveness of four weed control strategies in forest setting stands linked by a set of Atlantic Forest tree species. Four treatments were employed: mechanical - manual hoeing and mowing; chemical - glyphosate herbicide application in the total area; chemical - cultural - herbicide spraying and herbaceous legume intercropping; chemical-mechanical - herbicide planting in rows and mowing in the interrows. Diameter, crown area and soil cover percentage of the eight tree species were assessed at 18 months. Herbicide spraying in total area promoted the greatest reduction in weed populations, as well as superior growth in height, diameter, crown area and soil cover of the tree species. More interventions were necessary in the treatment of mechanical weed control that has also shown the least growth of the tree species. The chemical method was the most effective in weed control and promoted the greatest growth of the tree species.
\end{abstract}

Keywords: weed control, competition, mechanical control, chemical control and glyphosate.

\section{Introduction}

Natural landscape has been reduced in many parts of the world to withstand different human activities. Only in the period between 1990 to 2015, according to Morales-Hidalgo et al. (2015), primary forest areas declined $2.5 \%$ globally and up to $10 \%$ in tropical areas. In this context, the Brazilian Atlantic Forest is inserted as a widely degraded landscape, with forest remnants mostly dominated by small fragments.

Reckoned the noteworthiness of restoring these areas, many countries have been seeking out measures to secure restoration and maintenance of natural landscapes. To achieve this goal, forest restoration emerges as one of the main strategies. As underlined by Martin (2017), the restoration process seeks to help in recovering degraded, damaged or destroyed ecosystems to ensure the survival of organisms and to provide goods and services to humans.

Frequently, forestry restoration projects are conducted from setting of stands by planting native tree species seedlings, in order to achieve higher percentage of canopy cover rapidly, a lower rate of grass cover and a higher density of native species (Brancalion et al., 2016). Nevertheless, this method has higher costs in comparison to other methods (Trentin et al., 2018), as it demands several activities in the deployment and maintenance of the forestry stand.

Some local factors contribute to increase the need of interventions in conducting forest restoration stands. The competition of native species with grass is featured in the Southeast of Brazil considering that many areas destined to forestry restoration have a background as grazing-lands, especially the species of the Urochloa gender, the so-called 'brachiaria' grasses. These species are widely adapted to prevailing over conditions of high sunlight radiation and temperature in the tropics (Zhong et al., 2018) and have an increased ability in capturing and converting resources as sunlight, water and nutrients (Haling et al., 2013). Thus, these grasses can harm the forest restoration success (Silva et al., 2018), becoming an important group of harmful weeds if not properly controlled.

${ }^{1}$ Universidade Federal Rural do Rio de Janeiro (UFRRJ), Seropédica, RJ, Brasil

${ }^{2}$ Embrapa Agrobiologia, Seropédica, RJ, Brasil 
Weed control in forest restoration is usually performed by employing mechanical techniques, as mowing and hoeing. However, as underlined by Vasic et al. (2009) in areas infested by fast-growing weeds, as the brachiaria grasses, the mechanical method is not so effective, in addition to having high cost attached to labour force (Gonçalves et al., 2018; Santos et al., 2018). Thereby, it is important to pursue controlling alternatives to weed species in forest setting stands aiming forestry restoration.

Chemical control via herbicides is one of the alternatives. On the other hand, regarding mechanical method, the application of glyphosate herbicide effectively eradicates weeds and promotes a greatest growth of tree species (Santos et al., 2018). The physicochemical characteristics of glyphosate indicate high water solubility (Sw; $10,500 \mathrm{mg} \mathrm{L}^{-1}$ ), acid dissociation constant ( $\mathrm{pKa} ; 2.3$ ), as well as low octanol-water partition coefficient (Kow) (Log Kow; -3.2), indicating strong hydrophilicity and a low Dissipation Time (DT50) (15 d), being a non-persistent product in the soil (PPDB, 2019). This product is degraded by microorganisms in soil, involving molecule cleavage, with posterior production of aminomethylphosphonic acid (AMPA) followed by water, carbon dioxide and phosphate (Santos et al., 2009).

Another strategy consists of cultural control by intercropping herbaceous legumes in the planting interrows. According to Amoghein et al. (2013), the fast-growing herbaceous legumes promote soil cover, reducing density of weeds and helping the soil recovery, which benefits forestry species.

This study aimed to assess the effectiveness of mechanical, chemical, chemical-cultural and chemical-mechanical weed control strategies in forest setting stands with Atlantic Forest tree species.

\section{Methods}

\subsection{Region and experimental areas characterization}

The experiment was conducted in an area of the Reserva Ecológica de Guapiaçu (REGUA), in the Cachoeiras de Macacu municipality, in Rio de Janeiro state (22 $27^{\prime} 32.26^{\prime \prime}$, $\left.43^{\circ} 45^{\prime} 53.72^{\prime \prime} \mathrm{W}\right)$. The region weather is classified as type Af indicating a tropical rainforest climate by Köppen with rainy summer and dry winter, without a markedly dry season. Average annual precipitation is $2050 \mathrm{~mm}$ with monthly means ranging from $337.8 \mathrm{~mm}$ (February) to $59.3 \mathrm{~mm}$ (July), according to Azevedo et al. (2018). Average annual temperature is $21.9^{\circ} \mathrm{C}$, and it could be noted that January was the hottest month $\left(25.3^{\circ} \mathrm{C}\right)$ and July the coldest one $\left(17.9^{\circ} \mathrm{C}\right)$.
The area was originally occupied by livestock grazing pasture, with predominance of brachiaria grasses (Urochloa sp.), especially $U$. brizantha cv. Marandu and $U$. mutica (Forssk) T.O. Nguyen. A month previous to the study, the livestock was removed and the experimental area was fenced.

The area relief ranges from plain to soft wavy $\left(5\right.$ to $\left.15^{\circ}\right)$ with mean altitude of $35 \mathrm{~m}$. The area soil was classified as an Inceptic Hapludox (Oxisols), according to Soil Taxonomy (Soil Survey Staff, 2014), with clay loam texture soil containing $49 \%$ of sand, $34 \%$ of clay and $17 \%$ of silt. The soil fertility analysis in the $0-25 \mathrm{~cm}$ layer presented the following results: $\mathrm{pH}=4.8 ; \mathrm{P}=2,1$ and $\mathrm{K}^{+}=167.0 \mathrm{mg} \mathrm{dm}{ }^{-3} ; \mathrm{Ca}^{2+}=0.4$; $\mathrm{Mg}^{2+}=0.4$ and $\mathrm{Al}^{3+}=1, .0$ cmolc dm${ }^{-3}$ and $3.7 \mathrm{dag} \mathrm{kg}^{-1}$ of organic matter.

\subsection{Experimental characterization}

The experiment was formed by four weed control methods (treatments): mechanical - manual hoeing in a $30 \mathrm{~cm}$ radius of the seedlings and mowing in the interrows, always performed where brachiaria grass exceeded $35 \mathrm{~cm}$ height; chemical - glyphosate herbicide spraying (Roundup NA) at $1.44 \mathrm{~kg} \mathrm{ha}^{-1}$ a.e. (four liters of the herbicide per hectare) (480 $\mathrm{g} \mathrm{L}^{-1}$ and $360 \mathrm{~g} \mathrm{~L}^{-1}$ of glyphosate isopropylamine salt of acid equivalent) prior to the tree species planting and always performed where the brachiaria grass exceeded $35 \mathrm{~cm}$ height; chemical-cultural - herbicide spraying in total area prior to the tree species planting, intercropping with herbaceous legumes and specific maintenance (hoeing, mowing and thinning); chemical-mechanical - herbicide spraying in the planting rows $(1.4 \mathrm{~m}$ width $)$ and mowing in interrows always performed where the brachiaria grass exceeded $35 \mathrm{~cm}$ height.

A randomized blocks design was adopted with four replicates and four treatments, totaling 16 sampling units. Each plot measured approximately $214 \mathrm{~m}^{2}(15 \mathrm{~m} \mathrm{x} 14 \mathrm{~m})$ and received five seedlings of eight tree species, such as: Alchornea sidifolia Müll. Arg. (tapiá); Cordia abyssinica R. Br. (babosa-branca); Cordia trichotoma (Vell.) Arrab. Ex Steud. (louro-pardo); Guarea guidonia (L.) Sleumer. (carrapeta); Inga edulis Mart. (ingá); Peltophorum dubim (Spreng.) Taub. (farinha-seca); Piptadenia paniculata Benth. (unha-de-gato) and Sparattosperma leucanthum (Vell.) K. Schum. (ipê-cinco-folhas). A total of 40 plants per plot. All the seedlings were produced at the REGUA forestry nursery, and placed in $9 \mathrm{~cm} \times 20 \mathrm{~cm}$ plastic bags (diameter $\mathrm{x}$ height).

Fifteen days prior to planting, herbicide was sprayed in total area of the chemical and chemical-cultural treatments and also in the planting rows of the chemical-mechanical treatment. In the planting day, a $60 \mathrm{~cm}$ diameter manual hoeing was performed in the mechanical treatment plots. 
Spacing adopted between seedlings was $3.0 \times 1.7 \mathrm{~m}$. Planting holes measuring $30 \times 30 \times 30 \mathrm{~cm}$ (length $\mathrm{x}$ width $\mathrm{x}$ depth) were opened manually and was applied 150 grams of organomineral fertilizer (Nitrogen-Phosphorus-Potassium (N-P-K) fertilizer)) (03-13-06). According to the label specifications, this fertilizer contains Cation Exchange Capacity (CEC) of $80 \mathrm{mmol} . \mathrm{kg}^{-1}$, including $8 \%$ of organic matter, $4 \%$ of Calcium $(\mathrm{Ca})$ and $4 \%$ of Sulphurum (S). Seedlings were distributed and planted according to the mentioned spacing of the plots. A replanting was performed 30 days after planting.

A month after planting, the first mowing was performed in the chemical-mechanical and mechanical treatments, followed by other mowings always where the brachiaria grass achieved $35 \mathrm{~cm}$ height. The operations were conducted with string trimmers.

The herbicide applications were performed with 20 liters knapsack sprayers, equipped with SF-110-015 nozzle at working pressure of $200 \mathrm{kPa}$. Dose calculation followed the label recommended specifications for brachiaria species found in the area and considered the weeds growth stage. To secure appropriate application (uniform application without spray drift effect), all operations were performed by trained applicator in-between 8:00 to 10:00 AM in days without rainfall forecast, relative humidity of $79 \pm 4 \%$, wind speed inferior to $10 \mathrm{~km} \mathrm{~h}^{-1}$ and temperature of $27.5 \pm 1^{\circ} \mathrm{C}$.

The chemical-cultural treatment was intercropped with Canavalia ensiformis (L.) DC. (jack bean) and Cajanus cajan (L.) Huth (pigeon pea) after decomposition of the brachiaria grass straw (five months after herbicide spraying). A planting furrow was opened in the interrows of the tree species where twelve seeds of pigeon pea were sown per linear meter. The jack bean sowing occurred in $0.4 \times 0.4 \mathrm{~m}$ spaced planting holes with three seeds on each. The remaining weed control operations took place in accordance to each treatment.

\subsection{Assessments}

Survival and growth assessments were performed at six, nine, 12, 15 and 18 months after planting. Height was measured with graduated ruler. The trees diameter at $5 \mathrm{~cm}$ Natural Ground Level (NGL) was measured at 12 and 15 months with digital caliper. At 18 months, the crown longitudinal (D1) and transversal (D2) lengths were measured with measuring tape. Data on crown length was used to determine the Aggregated Caliper inches (ACi) of canopy area of each tree and soil cover area through a perpendicular projection of the trees crown by the 'degree of coverage' (GC) (Müeller-Dombois \& Ellemberg, 1974) and 'Line-Intercept Sampling' (LIS) (Melo et al., 2007), by adopting the following Equations 1-3:
Crown area:

$A C_{i}=\frac{\pi^{*} D_{1}{ }^{*} D_{2}}{4}$

Coverage degree:

$G C=\left(\frac{\sum_{A C_{i}}}{S}\right) * 100$

Line-intercept:

$I L=\left(\frac{\Sigma_{D_{l}}}{C}\right)$

where: $\mathrm{AC}_{\mathrm{i}}=$ crown area of each individual tree $\left(\mathrm{m}^{2}\right)$; $\mathrm{D}_{1}$ e $\mathrm{D}_{2}=$ crown longitudinal and transversal length to the planting line $(\mathrm{m}) ; \mathrm{S}=$ area of the plot unit $\left(\mathrm{m}^{2}\right) ; \mathrm{C}=$ planting line length $(\mathrm{m})$.

The assessment of the treatments effect in reduction of the weed populations dry mass of the weeds was determined prior to the experiment deployment and again 19 months after planting. In each occasion, a $1.0 \times 1.0$ m quadrant was randomly placed in four different points of the plot. Shoots of weeds in the quadrant were collected, trialed in laboratory, placed in paper bags and oven-dried at $65^{\circ} \mathrm{C}$ for 72 hours to determine dry mass. Reduction of the weed infestation in each treatment was calculated using the Equation 4:

$R I=\frac{\left(M_{0}-M_{19}\right)}{M_{0}} * 100$

where: $\mathrm{RI}=$ reduction of the infestation (\%); $\mathrm{M}_{0}=$ dry mass of the weeds per $\mathrm{m}^{2}$ prior to the tree species planting; $\mathrm{M}_{19}=$ dry mass of the weed per $\mathrm{m}^{2}$ at 19 months after planting.

At 12 months after planting trees, the pigeon peas flowering and the jack bean fruiting occurred and measurements of growth and canopy cover were determined for both legume species.

To calculate the mean number of pigeon pea plants per linear meter, a measuring tape was stretched in the planting line and each individual plant was counted, considering two planting lines per plot. Two plants in each planting line was randomly collected to assess height and dry mass. Soil cover percentage of the pigeon peas was determined by multiplying longitudinal and transversal lengths to the planting line.

To determine canopy cover of the jack bean plants, an adaptation of the Rizzardi \& Fleck (2004) method was employed and this method consisted of taking photographs of a 1.0 meter wood frame in the quadrant with a mesh of equally spaced threads, using two replicates per plot. The number of intersections (points) that overlapped the plant leaves were counted and divided by the total number of intersections. The number of jack bean plants in the quadrant were counted to obtain the number of plants per $\mathrm{m}^{2}$ and then the plants were cut close to ground level. The plants were placed in paper bags and in drying oven at $65^{\circ} \mathrm{C}$ for 72 hours to obtain dry mass per $\mathrm{m}^{2}$. 


\subsection{Statistical analysis}

Variance data of the tree species growth measurements in height, diameter and crown area at 18 months and soil cover of each treatment and dry mass of the weeds at 19 months were submitted to the Bartlett's test for homogeneity of variance and the residues normality were tested through the Shapiro-Wilk's test.

When the assumptions were not satisfied, data were transformed by the Box-Cox method (Box \& Cox, 1964) to have an approximately normal distribution. Subsequently, a variance analysis was conducted and in case of significance $(p>0.05)$ the data was submitted to the Tukey's test to compare means at $5 \%$ significance.

\section{Results and discussion}

Considering all operations performed up to 19 months after planting, the mechanical treatment had the greatest number of weed control interventions with a total number of 13 , followed by the chemical-mechanical (10), chemical-cultural (8) and chemical (6) treatments (Table 1).

Due to the legumes intercropping, a greater diversity of controlling operations (Table 1) occurred in the chemical - cultural treatment. In addition to herbicide spraying and sowing of jack and pigeon peas, a mowing with a scythe were conducted in the jack beans that were close to the tree species planting lines, even as a mowing of the herbaceous plants (basically jack bean and brachiaria grasses), and finally, a pruning of the pigeon peas.

Mowing operations were constant during the experiment. In the mechanical treatment, a mowing was performed at every 2.5 months, whilst in the chemical-mechanical treatment, the operation was performed at every 3.8 months. It is expected a greater number of interventions, when weed control is performed mechanically. As underlined by Vasic et al. (2009), mechanical treatment tends to be less effective in areas dominated by species with upper revegetation potential, such as areas with brachiaria grass predominance, considering that these plants are widely adapted to high sunlight radiation and temperature conditions encountered in the tropics (Zhong et al., 2018) and that were genetically improved to have vigorous growth after livestock grazing (Araújo et al., 2008). Regarding the manual hoeing have presented longer effect in weed control, five operations were performed in 19 months, three less than initially scheduled (Table 1).

Herbicide applications occurred in less number than mowing operations (Table 1), as also reported by Santos et al. (2018). The greatest number of applications occurred in the chemical treatment, with mean of one intervention at every 4.0 months in the total experiment period. This treatment promoted the greatest reduction effect in the weed population. At 19 months after planting of the tree species saplings, biomass of the weed population was $97 \%$ inferior than observed in the beginning of the experiment (Figure 1).

Even with a significant number of interventions (Table 1), the mechanical treatment had the poorest effect in reducing weed infestation (60\%), when compared to the chemical and chemical-cultural treatments. Considering mean infestation of weeds in planting lines and interrows, the chemical-mechanical treatment has shown the least reduction, with $45 \%$ (Figure 1).

The glyphosate action mechanism inhibits production of aromatic amino acids in the shikimate pathway (Amrhein et al., 1980), leading to death of the plants. And thus, it diminishes resprouting potential and promotes a longer effect and a bigger interval between applications (Table 1). Similar results were observed by Vasic et al. (2014) assessing effectiveness of the

Table 1. Maintenance operations, number of interventions and times of the experiment involving Urochloa spp. by controlling strategies up to 19 months after the tree species planting in the municipality of Cachoeiras de Macacu, RJ.

\begin{tabular}{|c|c|c|c|}
\hline Treat. & Operations & Numb. & Times (month/year) \\
\hline \multirow{2}{*}{ Mechanical } & Manual Hoeing* & 5 & May and Sep / 2017; Feb, Jul and Dec / 2018. \\
\hline & Total area of grass mowing ${ }^{\star *}$ & 8 & Jun, Sep and Nov / 2017; Feb, Apr, Jul, Oct and Dec / 2018. \\
\hline \multirow{3}{*}{ Chemical } & Herbicide application in total area ${ }^{* * *}$ & 4 & May e Nov / 2017; Feb and Aug / 2018. \\
\hline & Targeted herbicide application & 1 & Aug / 2017. \\
\hline & Brachiaria grass mowing* & 1 & Oct / 2017. \\
\hline \multirow{6}{*}{ Chemical-cultural } & Herbicide application in total area & 2 & May / 2017 and Aug / 2018. \\
\hline & Targeted herbicide application & 1 & Aug / 2017. \\
\hline & Herbaceous legumes sowing & 1 & Oct / 2017. \\
\hline & Brachiaria grass mowing * & 1 & Nov / 2017. \\
\hline & Total area of grass mowing & 1 & Apr / 2018. \\
\hline & Legumes pruning & 2 & Jan and Aug / 2018. \\
\hline \multirow{3}{*}{ Chemical-mechanical } & Herbicide application in strips ${ }^{* * *}$ & 4 & May / 2017; Jan, Jul and Dec / 2018. \\
\hline & Interrow mowing ${ }^{\star *}$ & 5 & Aug and Dec / 2017; Feb, Jul and Dec / 2018. \\
\hline & Brachiaria grass mowing & 1 & Oct / 2017. \\
\hline
\end{tabular}

${ }^{*} 60 \mathrm{~cm}$ diameter; ${ }^{* *}$ String trimmers in the interrows of tree species lines; ${ }^{* *}$ Knapsack sprayer, dose of 4.0 liters per hectare of glyphosate herbicide. 


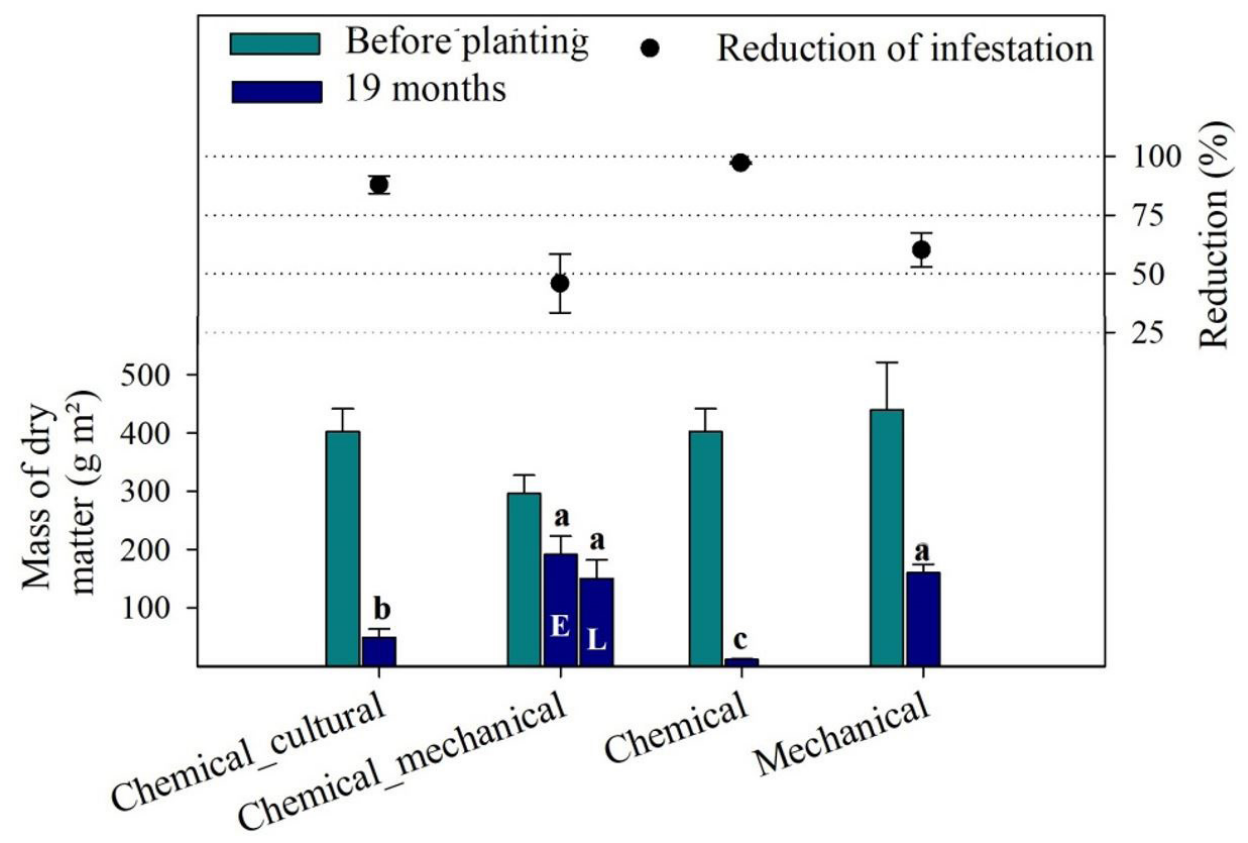

Figure 1. Mean and Standard Deviation (SD) in dry mass of weeds prior to the planting and at 19 months after planting and reduction of weed infestation in reforestation area submitted to weed control strategies, in the municipality of Cachoeiras de Macacu, RJ. For the chemical-mechanical treatment, the bar which contains the letter "E" refers to the average amount of dry matter production of the herbaceous plants between the rows and the bar "L" refers to the planting line. For evaluation at 19 months, different letters between bars indicate that treatments differ statistically at $5 \%$ by Tukey's test.

post-emergence herbicides nicosulfuron, bentazon, imazamox and tribenuron-methyl in suppressing weeds in Quercus robur L. setting stands in North America. The authors observed that in areas without herbicide spraying or that in which the areas were submitted to mechanical control, abundance and biomass production of the weeds was higher when compared to areas with herbicide application, resulting in decreased plant growth in height and diameter.

The greatest reduction in weed population was observed in the chemical and chemical-cultural treatments (Figure 1) and contributed to the superior survivorship of the tree species (Figure 2). The chemical treatment has shown the greatest mean survivorship percentage after 18 months (95.8\%), whilst the lowest survivorship was obtained in the chemical-mechanical treatment $(82.5 \%)$, considering mean of the eight tree species.

By analyzing survivorship percentage per species separately, it was observed that I. edulis was the only species that has not had mortality of saplings during the study and has shown statistically equal growth in height in the treatment. This result pointed out that the species is well-adapted to the experiment region and was less sensitive to the weed competition. On the other side, the lowest survivorship index (50\%) was reported in $P$. paniculata in the mechanical treatment, probably due to the species highly sensibility to weed competition and requirement of low infestation conditions to its proper establishment. In the chemical-cultural and chemical treatments, this species has shown high survivorship percentage and growth in height (Figure 2).

Most of the tree species has shown pronounced growth in height (Figure 2) and in diameter at $5 \mathrm{~cm}$ above ground level and crown area (Figure 3 ) in the chemical-cultural and chemical treatments. In this latter, at 18 months after planting, mean growth of the plants was $78 \%$ superior in height, $91 \%$ in diameter and $250 \%$ in crown area when compared to the mechanical treatment, which had the lowest growth. In addition, diameter growth assessment at 12 months after planting in the chemical and chemical-cultural treatments (Figure 3) was numerically higher than those observed in the mechanical treatment at 18 months, indicating a rapidly development of the plants in the glyphosate herbicide treatments. Considering the three variables, the best-ranked treatments were: chemical, chemical-cultural, chemical-mechanical and mechanical.

In the last assessment of the tree species, the plants growth in the chemical treatment was statistically superior than in the chemical-mechanical treatment. It indicates that in the conditions in which this study was conducted, herbicide spraying in strips of $1.4 \mathrm{~m}$ in planting lines and mowing in the interrows was not satisfactory in controlling weeds, in other words, reducing the competition (Figure 1) and thus favoring growth of the tree species.

It is possible that the spraying band may have been too narrow to the conditions in which the experiment was 


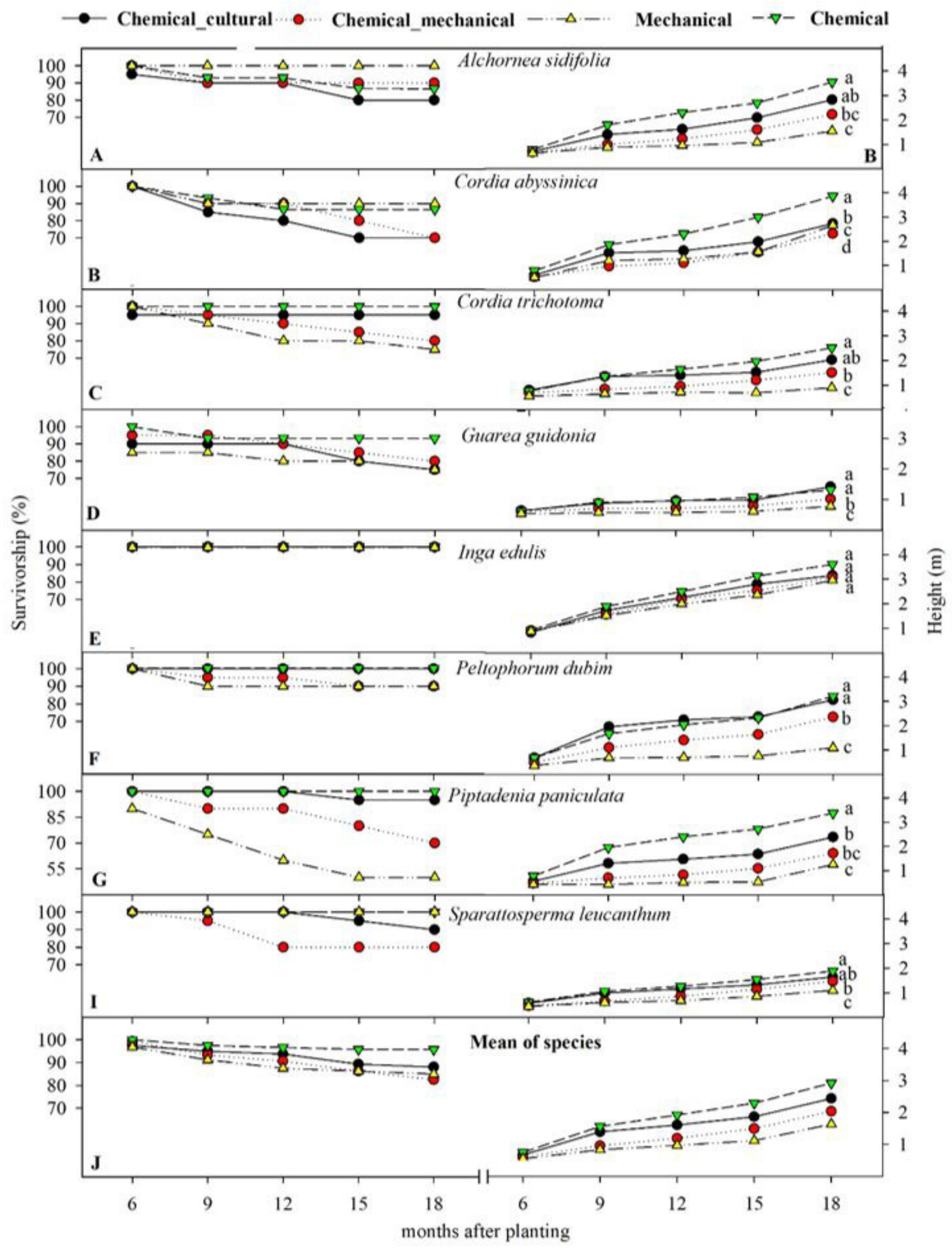

Figure 2. Survivorship (left axis) and height (right axis) in different times after planting of eight tree species submitted to weed control strategies in reforestation area, in the municipality of Cachoeiras de Macacu, RJ. To each species, different letters indicates that treatments differ at $5 \%$ significance by Tukey's test, in the last assessment. 


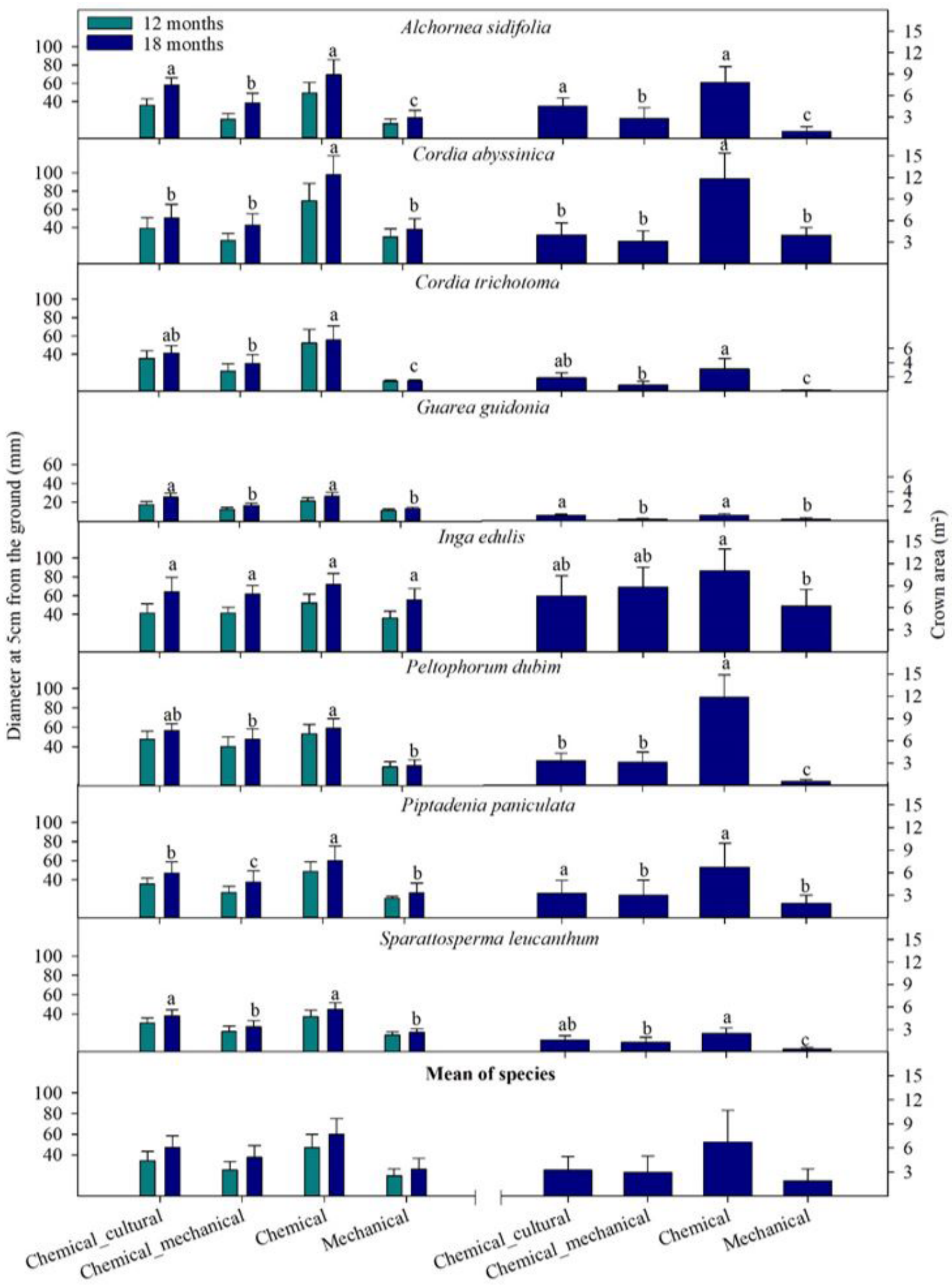

Figure 3. Diameter at $5 \mathrm{~cm}$ above ground level (left axis) at 12 and 18 months after planting and crown area (right axis) at $18 \mathrm{months}$ of eight tree species submitted to weed control strategies in reforestation area, in the municipality of Cachoeiras de Macacu, RJ. Standard Deviation (SD) is represented by vertical bars. 
conducted. In the weed control assessment of three tree species through manual hoeing and chemical methods, Maciel et al. (2011) have concluded that a single application of glyphosate herbicide spray solution $\left(0.72 \mathrm{~kg}\right.$ e.a ha $\left.{ }^{-1}\right)$ in a $1.0 \mathrm{~m}$ diameter area surrounding the saplings was not efficient in favoring early growth of the native forest species studied. These observations, allied to results found in this study, may suggest the need to investigate other band widths in controlling brachiaria grass with herbicides to forest setting stands aiming forestry restoration, in different edaphic and weather conditions.

Mean values of infestation (Figure 1) and growth of the tree species (Figures 2 and 3) in the chemical-cultural treatment have shown the closest result regarding to that found in the chemical treatment. Growth of the plants was remarkably higher in the chemical-cultural treatment in comparison to the mechanical one.

It could be observed that after seven months of cultivation (twelve months after planting of the tree species), C. cajan plants exceeded 3 meters in height and promoted soil cover of 33\% in the plots. On the other hand, C. ensiformis plants showed mean soil cover of $45 \%$ and summed biomass production of $134 \mathrm{~g} \mathrm{~m}^{-2}$ (Table 2). The cultivation of fast-growing herbaceous legumes usually helps in the promotion of rapid soil cover, by reducing sunlight availability to weeds and favoring the establishment and growth of the tree species implanted, as reported by Santos et al. (2013).

Studying the relation of sunlight radiation interception and weed control needs in setting stands of Acacia mearnsii Wild., Eucalyptus grandis W. Hill e.g. Maiden, Mimosa scabrella Benth and Ateleia glazioviana Baill., Caron et al. (2012) reported that as sunlight radiation interception increases by the opening in the forest canopy of tree species, there is minor necessity in controlling weeds. It could be verified that higher values of crown area in the chemical treatment (Figure 3) influenced soil cover up to values exceeding $100 \%$ at 18 months (Figure 4), indicating that occurred overlapping of the tree crowns in the plots.

Probably, the eradication of weeds by herbicide application in total area in the beginning of the experiment has favored a rapid growth of the tree species (Figures 2 and 3) as well as higher soil cover percentage (Figure 4) by decreasing sunlight availability. And thus, weeds had lesser growth rate and consequently have had suppressed necessity of weed controlling interventions for a longer time span (Table 1).
Results are suggesting that herbicide application in total area is more effective than the remaining strategies adopted in this study. Santos et al. (2018) evaluated the employment of using predominant glyphosate herbicide treatment and mechanical treatment only in the forest setting stands in forestry restoration areas highly infested by brachiaria grasses and reported similar results to this current study. The authors reported that for glyphosate herbicide applications, it were necessary up to 13 months and that at 30 months the plants growth in height and diameter were significantly higher in the chemical treatment, in parallel to the costing of the mechanical treatment to be nearly three times more expensive.

On the contrary, considering the remaining control methods, herbicide may be adopted in short time span. In this study, the last application was performed at 15 months after planting. As highlighted by Kogan \& Alister (2010), glyphosate spraying in forestry areas may be necessary only in the first two years of the forest setting stand in order to assure the plants growth, by obtaining rapid soil coverage and contributing to natural rehabilitation. After such period, it is still possible to occur a competition of the slow-growing tree species with weeds, although, is more likely that such effect should be

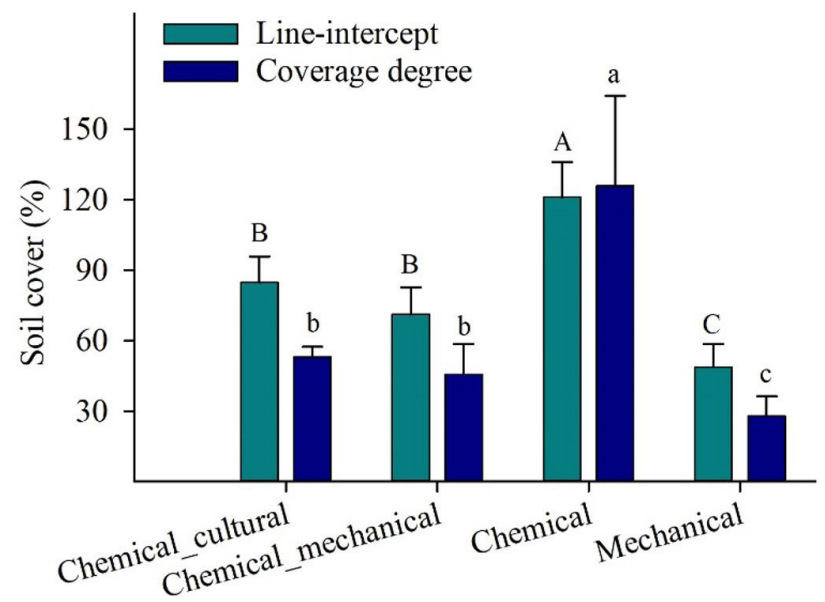

Figure 4. Soil cover of the eight tree species, through line-interception and coverage degree at 18 months after planting, submitted to weed control strategies in reforestation area in the municipality of Cachoeiras de Macacu, RJ. To each variable, different letters indicate that treatments differ between them by Tukey's test at $5 \%$.

Table 2. Mean and Standard Deviation (SD) of the growth and soil cover percentage of herbaceous legumes plants at seven months after sowing, in reforestation area in the municipality of Cachoeiras de Macacu, RJ.

\begin{tabular}{|c|c|c|c|}
\hline \multicolumn{2}{|c|}{----- Cajanus cajan (pigeon pea) ----- } & \multicolumn{2}{|c|}{---- Canavalia ensiformis (jack bean) ------ } \\
\hline characteristic assessment & Mean \pm SD & characteristic assessment & Mean \pm SD \\
\hline $\mathrm{N}^{\circ}$ of plants (m / row) & $6.75(1.58)$ & $\mathrm{N}^{\circ}$ of plants $\left(\mathrm{m}^{2}\right)$ & $4.33(0.33)$ \\
\hline Dry mass (g / plant) & $399.7(39.8)$ & Dry mass $\left(\mathrm{g} / \mathrm{m}^{2}\right)$ & $133.8(29.8)$ \\
\hline Height (m) & $3.14(0.81)$ & 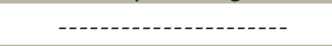 & 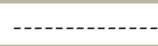 \\
\hline Soil cover $(\%)$ & $33.1(3.2)$ & Soil cover $(\%)$ & $45.2(3.8)$ \\
\hline
\end{tabular}


local, demanding targeted herbicide spraying or mowing of the grasses and shrubs.

According to these results, it is mandatory to increase discussions on employment of glyphosate herbicide in forest setting stands aiming restoration of the Atlantic Forest. It is necessary further studies for evaluating limitations of the chemical weed control method, possibility related to contamination of soil and water bodies and effect on non-targeted organisms.

Among limitations of using glyphosate in forestry restoration areas, spray drift possibility is a key factor, considering the non-selective characteristic of this product. In this study, it could be observed that only $0.4 \%$ of the plants in herbicide application treatments had phytotoxicity signals of having contact to the spray solution. Contamination signals occurred after spraying have been performed up to nine months after planting and these contaminations were characterized by chlorosis, leaf rolling in new sprouts and deformed apical meristem, as also reported by Tuffi Santos et al. (2006) in eucalyptus. Low number of toxicity symptoms in plants indicated that technology and cares adopted during herbicide application may prevent spray drift in areas with native tree species.

The lower soil cover percentage in the mechanical treatment after 19 months, resulting of the slow-paced growth of the tree species (Figure 2 and 3), suggests a reflection. Presence of weeds is one of the limiting factors in the establishment and survival of native tree species (Ruwanza et al., 2013; Silva et al., 2018). In highly infested conditions, the employment of techniques that are not effective may jeopardize the restoration area success, in addition to raise the project cost.

\section{Conclusion}

The herbicide treatment in total area had remarkable effect in reducing weed populations and promoted significant growth in height, diameter, crown area and soil cover in the planted species at 18 months after planting being the most effective weed controlling method in the Atlantic Forest restoration.

\section{Acknowledgements}

To the Reserva Ecológica do Guapiaçu for ceding the area, labor force and support to carry out the study. This project was supported by Coordenação de Aperfeiçoamento de Pessoal de Nivel Superior - Brasil (CAPES) - Funding Code 001.

\section{Submission status}

Received: 30 May, 2019

Accepted: 10 Feb., 2020

Associated Editor: Marcel Carvalho Abreu (ORCID: 0000-00026457-421X).

\section{Correspondence to \\ João Elves da Silva Santana}

Rodovia BR 465, Km 07, s/n, 23890-000, Seropédica, RJ, Brasil

e-mail: joao-elvis@outlook.com

\section{References}

Amoghein MB, Tobeh A, Gholipouri A, Jamaati-e-Somarin S, Ghasemi M. Effect of cover crop in control of weed density and some qualitative and quantitative characteristics of sunflower. International Journal of Agriculture and Crop Sciences 2013; 5(12): 1318-1323.

Amrhein N, Deus B, Gehrke P, Steinrücken HC. The Site of the Inhibition of the Shikimate Pathway by Glyphosate. Plant Physiology 1980; 66(5): 830-834. http://dx.doi.org/10.1104/pp.66.5.830. PMid:16661535.

Araújo SAC, Deminicis BB, Campos PRSS. Melhoramento genético de plantas forrageiras tropicais no Brasil. Archivos de Zootecnia 2008; 57: 61-76.

Azevedo AD, Francelino MR, Camara R, Pereira MG, Leles PSS. Estoque de carbono em áreas de restauração florestal da Mata Atlântica. Floresta 2018; 48(2): 183-194. http://dx.doi.org/10.5380/ rf.v48i2.54447.

Brancalion PHS, Schweizer D, Gaudare U, Mangueira JR, Lamonato F, Farah FT et al. Balancing economic costs and ecological outcomes of passive and active restoration in agricultural landscapes: the case of Brazil. Biotropica 2016; 48(6): 856-867. http://dx.doi.org/10.1111/ btp. 12383 .

Box GEP, Cox DR. An analysis of transformations. Journal of the Royal Statistical Society. Series A (General) 1964; 26(2): 211-252.

Caron BO, Souza VQ, Costa EC, Eloy E, Behling A, Trevisan R. Interceptação da radiação luminosa pelo dossel de espécies florestais e sua relação com o manejo das plantas espontâneas. Ciência Rural 2012; 42(1): 75-82. http://dx.doi.org/10.1590/S010384782012000100013 .

Gonçalves FLA, Resende AS, Lima LSS, Chaer GM. Manual crowning versus cardboard in forest restoration: costs and effect on seedling development. Planta Daninha 2018; 36(0): 1-10. http://dx.doi. org/10.1590/s0100-83582018360100107.

Haling RE, Campbell CD, Tighe MK, Guppy CN. Effect of competition from a $\mathrm{C}_{4}$ grass on the phosphorus response of a subtropical legume. Crop \& Pasture Science 2013; 64(10): 985-992. http://dx.doi.org/10.1071/CP13275.

Kogan M, Alister C. Glyphosate use in forest plantations. Chilean Journal of Agricultural Research 2010; 70(4): 652-666. http://dx.doi. org/10.4067/S0718-58392010000400017.

Maciel CDG, Poletine JP, Alves IM, Raimondi MA, Rodrigues M, Ribeiro RB et al. Crowning in weed control and initial development of native forestry species. Semina: Ciências Agrárias 2011; 32(1): 119-128. http://dx.doi.org/10.5433/1679-0359.2011v32n1p119.

Martin DM. Ecological restoration should be redefined for the twentyfirst century. Restoration Ecology 2017; 25(5): 668-673. http:// dx.doi.org/10.1111/rec.12554. PMid:29400359.

Melo ACG, Miranda DLC, Durigan G. Cobertura de copas como indicador de desenvolvimento estrutural de reflorestamentos de restauração de matas ciliares no Médio Vale do Paranapanema, SP, Brasil. Revista Árvore 2007; 31(2): 321-328. http://dx.doi. org/10.1590/S0100-67622007000200015.

Morales-Hidalgo D, Oswalt SN, Somanathan E. Status and trends in global primary forest, protected areas, and areas designated for 
conservation of biodiversity from the Global Forest Resources Assessment 2015. Forest Ecology and Management 2015; 352: 68-77. http://dx.doi.org/10.1016/j.foreco.2015.06.011.

Müeller-Dombois D, Ellemberg H. Aims and methods of vegetation ecology. 1st ed. New York: Wiley e Sons; 1974.

Pesticide Properties Data Base - PPDB. Agriculture \& Environment Research Unit (AERU) [online]. University of Hertfordshire; 2019 [cited 2019 Nov]. Available from: https://sitem.herts.ac.uk/aeru/ ppdb/en/Reports/373.htm

Rizzardi MA, Fleck NG. Métodos de quantificação da cobertura foliar da infestação de plantas daninhas e da cultura da soja. Ciência Rural 2004; 34(1): 13-18. http://dx.doi.org/10.1590/S010384782004000100003.

Ruwanza S, Gaertner M, Esler KJ, Richardson DM. The effectiveness of active and passive restoration on recovery of indigenous vegetation in riparian zones in the Western Cape, South Africa: a preliminary assessment. South African Journal of Botany 2013; 88: 132-141. http://dx.doi.org/10.1016/j.sajb.2013.06.022.

Santos FAM, Leles PSS, Santana JES, Nascimento DF, Machado AFL. Controle químico de plantas daninhas em povoamentos de restauração florestal. Pesquisa Florestal Brasileira 2018; 38: 1-9. http://dx.doi.org/10.4336/2018.pfb.38e201701524.

Santos JB, Ferreira EA, Fialho CMT, Santos EA, Galon L, Concenço $\mathrm{G}$ et al. Biodegradation of glyphosate in rhizospheric soil cultivated with Glycine max, Canavalia ensiformis e Stizolobium aterrimum. Planta Daninha 2009; 27(4): 781-787. http://dx.doi.org/10.1590/ S0100-83582009000400016.

Santos JCF, Cunha AJ, Ferreira FA, Santos RHS, Sakiyama NS, Lima PC. Cultivation of perennial herbaceous legumes in weed management in coffee plantation on the Cerrado. Journal of Agricultural Science and Technology 2013; 3: 420-428.

Silva AP, Resende AS, Chaer GM, Gonçalves FLA, Campello EFC. Influência da forma e posição da encosta nas características do solo e na regeneração natural em áreas de pastagem abandonadas. Ciência Florestal 2018; 28(3): 1239-1252. http://dx.doi.org/10.5902/1980509833366.

Soil Survey Staff. Keys to Soil Taxonomy. 12th ed. Washington, DC: USDA Soil Conservation Service; 2014. 362 p.

Trentin BE, Estevan DA, Rossetto EFS, Gorenstein MR, Brizola GP, Bechara FC. Restauração florestal na Mata Atlântica: passiva, nucleação e plantio de alta diversidade. Ciência Florestal 2018; 28(1): 160-174. http://dx.doi.org/10.5902/1980509831647.

Tuffi-Santos LD, Ferreira FA, Ferreira LR, Duarte WM, Tiburcio RAS, Santos MV. Intoxicação de espécies de eucalipto submetidas à deriva do Glyphosate. Planta Daninha 2006; 24(2): 359-364. http:// dx.doi.org/10.1590/S0100-83582006000200020.

Vasic V, Konstantinovic B, Orlovic S. Application of post-emergence herbicides in the regeneration of pedunculate oak (Quercus robur L.) forests. Forestry 2014; 87(3): 407-415. http://dx.doi.org/10.1093/ forestry/cpt060.

Vasic V, Orlovic S, Galic Z. Forest vegetation and managementSerbia. In: Willoughby I, Balandier P, Bentsen NS, McCarthy N, Claridge J, editor. Forest vegetation management in Europe. Brussels: COST Office; 2009.

Zhong J, Robbett M, Poire A, Preston JC. Successive evolutionary steps drove Pooideae grasses from tropical to temperate regions. The New Phytologist 2018; 217(2): 925-938. http://dx.doi.org/10.1111/ nph.14868. PMid:29091285. 